\title{
Ammonium Attenuation in Aquifer Material Impacted With High Levels of Organic Wastes
}

Final Report

August 1997

\author{
By: \\ Terry H. Brown
}

Work Performed Under Contract No.: DE-FC21-93MC30126

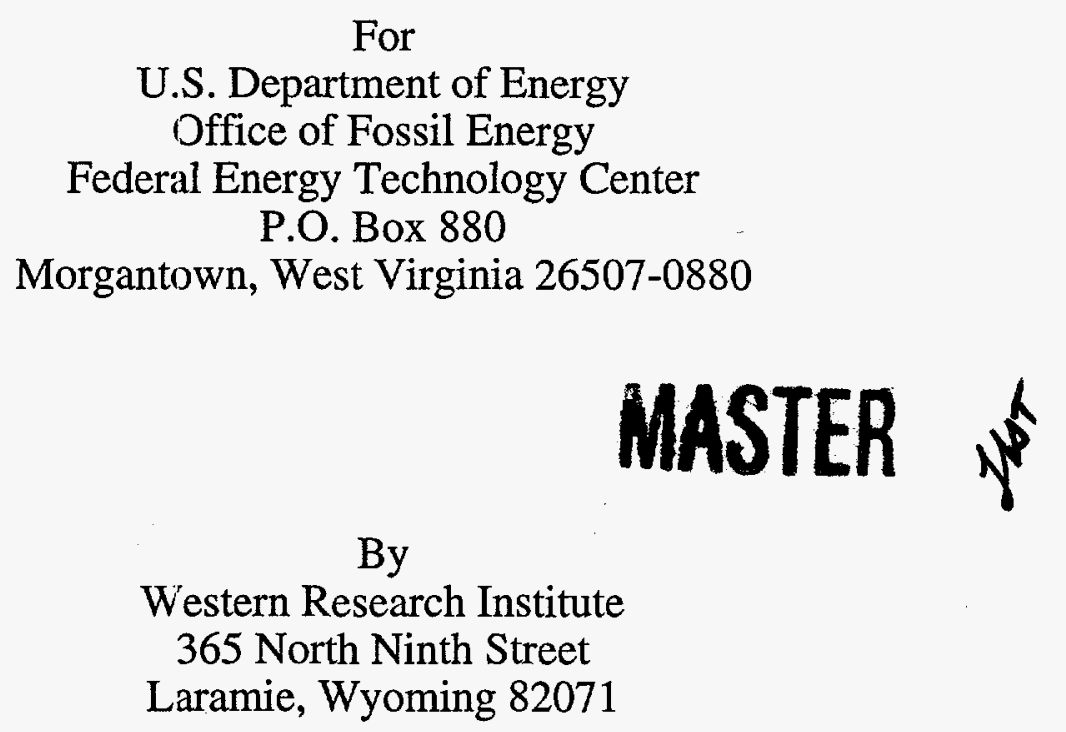

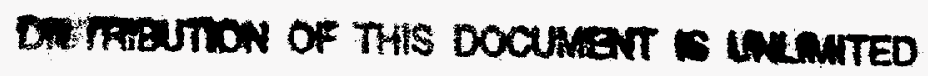




\section{Disclaimer}

This report was prepared as an account of work sponsored by an agency of the United States Government. Neither the United States Government nor any agency thereof, nor any of their employees, makes any warranty, express or implied, or assumes any legal liability or responsibility for the accuracy, completeness, or usefulness of any information, apparatus, product, or process disclosed, or represents that its use would not infringe privately owed rights. Reference herein to any specific commercial product, process, or service by trade name, trademark, manufacturer, or otherwise does not necessarily constitute or imply its endorsement, recommendation, or favoring by the United States Government or any agency thereof. The views and opinions of authors expressed herein do not necessarily state or reflect those of the United States Government or any agency thereof. 


\section{DISCLAIMER}

Portions of this document may be illegible electronic image products. Images are produced from the best available original document. 


\section{TABLE OF CONTENTS}

\section{Page}

LIST OF TABLES AND FIGURES …..................................................................... iv

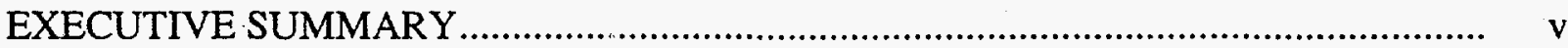

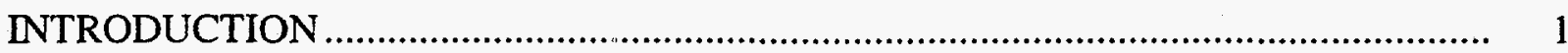

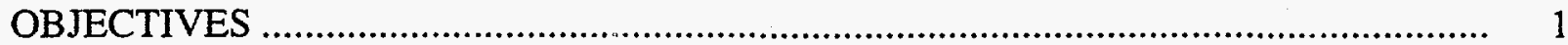

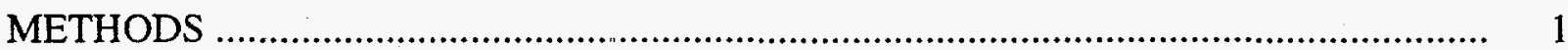

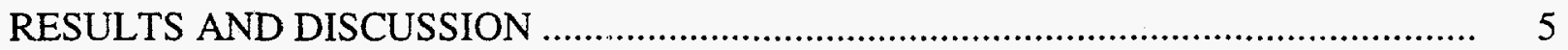

Tests - Uncontaminated Aquifer Material and

Ammonium-Contaminated Ground Water............................................................. 5

Tests - Ammonium-Contaminated Aquifer Material and

Uncontaminated Ground Water....

CONCLUSIONS

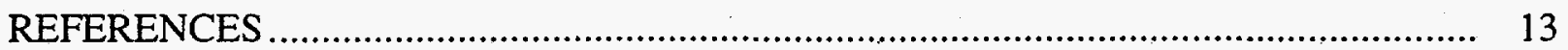

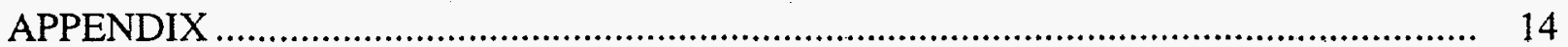




\section{LIST OF FIGURES AND TABLES}

Figures

Page

1. Run 1 - The Levels of Ammonium and Nitrate in Leachate from MW1 Aquifer Material Leached with MW6 Ground

2. Run 2 - The Levels of Ammonium and Nitrate in Leachate from MW1 Aquifer Material Leached with MW6 Ground Water.

3. Run 3-The Levels of Ammonium and Nitrate in Leachate from MW1 Aquifer Material Leached with MW6 Ground Water

4. . Run 4-The Levels of Ammonium and Nitrate in Leachate from MW1 Aquifer Material Leached with MW6 Ground Water.

5. Run 5 - The Levels of Ammonium and Nitrate in Leachate from MW1 Aquifer Material Leached with MW6 Ground Water

6. Run 6-The Levels of Ammonium and Nitrate in Leachate from MW6 Aquifer Material Leached with MW1 Ground Water.

7. Run 7 - The Levels of Ammonium and Nitrate in Leachate from MW6 Aquifer Material Leached with MW1 Ground Water.

8. Run 8 - The Levels of Ammonium and Nitrate in Leachate from MW6 Aquifer Material Leached with MW1 Ground Water.

\section{Tables}

1. Run 1 (5/4/95) - MW6 Ground Water with MW1 Aquifer Material

2. Run $2(5 / 10 / 95)$ - MW6 Ground Water with MW1 Aquifer Material

3. Run $3(5 / 11 / 95)$ - MW6 Ground Water with MW1 Aquifer Material

4. Run $4(5 / 16 / 95)$ - MW6 Ground Water with MW1 Aquifer Material

5. Run $5(5 / 19 / 95)$ - MW6 Ground Water with MW1 Aquifer Material

6. Run $6(5 / 23 / 95)$ - MW6 Aquifer Material and MW1 Ground Water

7. Run $7(5 / 31 / 95)$ - MW6 Aquifer Material and MW1 Ground Water

8. Run $8(6 / 7 / 95)$ - MW6 Aquifer Material and MW1 Ground Water 


\section{EXECUTIVE SUMMARY}

Total concentrations of ammonium $\left(\mathrm{NH}_{4}{ }^{+1}\right)$ have been found to exceed the State of Wyoming ground water quality standard for Class I aquifers near Torrington, Wyoming. The cause of the $\mathrm{NH}_{4}{ }^{+1}$ contamination is thought to be associated with fertilizer use and/or the leaching of organics into the ground water from impoundments holding wastes from sugar beet processing. This type of contamination could be expected from other industrial processes, including those associated with the use of fossil fuels. In an initial step in understanding and solving the ground water contamination problem, Western Research Institute (WRI) conducted a laboratory investigation to understand the aquifer system as it relates to the chemistry of $\mathrm{NH}_{4}{ }^{+1}$ as it moves through the aquifer material.

The data collected during the attenuation tests do provide an indication that the attenuation of $\mathrm{NH}_{4}{ }^{+1}$ in the ground water system will occur. In addition, the results show the redox condition of the site and the possible chemical reactions that are influencing the ground water quality.

The tests completed with unimpacted aquifer material leached with $\mathrm{NH}_{4}{ }^{+1}$ contaminated ground water show that dilution of $\mathrm{NH}_{4}{ }^{+1}$ does occur at the front of the plume as it moves through the aquifer material. Apparently, the dilution is primarily a result of diffusion and hydrodynamic dispersion with some retardation due to electrostatic forces. In addition, the mixed system appears to have a redox condition that is poised at Eh values between +180 and $+200 \mathrm{mv}$ and a $\mathrm{pH}$ value of about 7.9. This phenomenon is caused by some unknown redox couple.

The system of $\mathrm{NH}_{4}{ }^{+1}$ contaminated aquifer material leached with uncontaminated ground water used to evaluate removal of $\mathrm{NH}_{4}^{+1}$ from the $\mathrm{MW} 6$ aquifer material had a poised redox condition of about $+180 \mathrm{mv}$ to $+200 \mathrm{mv}$. In addition, the relatively high levels of $\mathrm{NO}_{3}{ }^{-1}$ leached from the system could be due to either (1) the inadvertent incorporation of air into the system during sample setup, promoting nitrification or (2) the depletion of $\mathrm{Fe}^{+2}$ concentrations, allowing nitrification to occur. Additional studies would be required to determine the phenomena causing the formation of $\mathrm{NO}_{3}^{-1}$ in this system. 


\section{INTRODUCTION}

Total concentrations of ammonium $\left(\mathrm{NH}_{4}{ }^{+1}\right)$ have been found to exceed the State of Wyoming ground water quality standard for Class I aquifers near Torrington, Wyoming. The cause of the $\mathrm{NH}_{4}{ }^{+1}$ contamination is thought to be associated with fertilizer use and/or the leaching of organics into the ground water from impoundments holding wastes from sugar beet processing. This type of contamination could be expected from other industrial processes, including those associated with the use of fossil fuels. In an initial step in understanding and solving the ground water contamination problem, Western Research Institute (WRI) conducted a laboratory investigation to understand the aquifer system as it relates to the chemistry of $\mathrm{NH}_{4}{ }^{+1}$ as it moves through the aquifer material.

\section{OBJECTIVE}

The objective of this study was to estimate the attenuation of the $\mathrm{NH}_{4}{ }^{+1}$ as it moves through the aquifer material. Attenuation of $\mathrm{NH}_{4}{ }^{+1}$ was evaluated by studying the movement of contaminated ground water through nonimpacted aquifer material. In addition, nonimpacted ground water was leached through contaminated aquifer material to determine if the $\mathrm{NH}_{4}{ }^{+1}$ present in the aquifer material could be readily mobilized and dispersed.

\section{METHODS}

The ground water and aquifer material (overburden) samples were to represent the ground water and aquifer material from $\mathrm{NH}_{4}{ }^{+1}$ impacted and nonimpacted areas. Aquifer material and water samples were collected from, and adjacent to, well MW1, which represented a nonimpacted site, and Well MW6, which represented an impacted site. Samples of the aquifer material were collected using a backhoe. These samples were collected at levels below the capillary fringe of the aquifer. Ground water samples were collected from pre-existing monitoring wells MW1 and MW6, which are located adjacent to the backhoe pits. The water samples were collected using a small diameter submersible pump. The pump was lowered to midwater depth in each well. Approximately 4 well volumes were removed from each well prior to sample collection. During the collection of the ground water samples, field parameters such as $\mathrm{pH}$, Eh and temperature (T) were determined using field meters. Ground water samples were submitted to Accu-Labs for analysis to establish baseline information.

The ground water and aquifer material collected for the attenuation tests were sampled and stored in a manner to help prevent the influence of air on the redox condition of the samples. 
Ground water samples were pumped from the well into preconditioned 5-gallon sealable containers. The containers were prepared by thorough rinsing with the ground water and then were purged with argon to remove the air (oxygen) from the container. The containers were filled, leaving zero head space, and capped to help eliminate changes in redox conditions. The aquifer material samples were placed in preconditioned 5-gallon plastic buckets. The buckets were initially purged with argon and filled about half full with ground water collected from the respective well. The aquifer materials were placed in the buckets directly from the backhoe. The buckets were sealed with plastic and duct taped. Following the collection of the samples, the samples were agitated by shaking to remove air trapped in the sample during removal from the aquifer. The air was removed from the container by purging the system with argon through a hole in the plastic sheet. The buckets were then resealed by taping the hole made for argon purging and taping another layer of plastic over the bucket. The ground water and aquifer material samples were shipped immediately after sampling to WRI's facilities and stored at about $4^{\circ} \mathrm{C}$.

In-place material densities were determined at the sampling locations to provide an approximate density to be used for the laboratory testing. Due to the sandy nature of the aquifer material and the resulting instability, these tests were conducted on materials at depths of about 4 feet that were very similar to the deeper aquifer materials. The field densities were determined with a sand cone apparatus in pits constructed using a front-end loader. Small excavations were made at two sites in each pit located near ground water wells MW1 and MW6. The excavated materials were collected and placed in plastic bags for wet and dry weight measurements. The amount of sand (by weight) required to fill the excavations was determined. The field bulk densities were calculated knowing the weight/volume relationship for the sand used and the dry weight of the material removed from the excavation.

The pore volume of the aquifer materials was determined using the method described in Methods of Soil Analysis - Part I (1982). The following equation is used to calculate the pore volume:

$$
S_{t}=\left(1-\rho_{b} / \rho_{p}\right)
$$

where $S_{t}=$ total porosity, $\rho_{p}=$ particle density, and $\rho_{b}=$ dry bulk density

The weighted average particle density was determined using the method described in Methods of Soil Analysis - Part 1 (1982). The following equation was used:

$$
\mathrm{G}_{\mathrm{avg}}=1 /\left(\left(\mathrm{R}_{1} / 100 \mathrm{G}_{1}\right)+\left(\mathrm{P}_{1} / 100 \mathrm{G}_{2}\right)\right)
$$


where $G_{a v g}=$ weighted average particle density, $R_{1}=\%$ of material $>4$ mesh sieve size, $P_{1}$ $=\%$ of material $<4$ mesh sieve size, $G_{1}=$ particle density of material $>4$ mesh sieve size, $\mathrm{G}_{2}=$ particle density of material $<4$ mesh sieve size

The particle density of each size fraction was determined using the following equation, discussed in the above-noted reference:

$$
\rho_{p}=\rho_{w}\left(W_{s}-W_{a}\right) /\left(\left(W_{s}-W_{a}\right)-\left(W_{s w}-W_{w}\right)\right)
$$

where $\rho_{p}=$ particle density, $\rho_{w}=$ density of water, $W_{s}=$ weight of container plus oven dry soil, $\mathrm{W}_{\mathrm{a}}=$ weight of container, $\mathrm{W}_{\mathrm{sw}}=$ weight of container plus soil, $\mathrm{W}_{\mathrm{w}}=$ weight of container plus water

Water samples removed from the storage containers for use in the permeameter were taken in a manner to reduce the influence of air on the redox condition of the samples. Ground water samples were removed from the sample containers very slowly and placed in plastic containers that had previously been purged with argon. The containers were filled, maintaining zero head space, subsequent to capping. Following the removal of the ground water sample from the storage container, the head space was purged with argon, and the container was capped and sealed.

Soil materials were removed from the sample buckets and compacted in the argonconditioned specimen tubes using a hand wand vibrating massager. The densities of the materials were approximately equal to the in-place densities of the materials tested using the sand cone apparatus. However, the compaction of the test columns was done using wet material to prevent the influence of air on the redox status of the samples. As a result, variation in water content between samples could cause the calculated dry densities to differ. However, an attempt was made to take water content into account during sample compaction.

After the samples were removed from the storage containers, the head space of the sample bucket was purged with argon gas to remove any oxygen present. The bulk density of the specimens closely resembled the field densities of in-place materials determined using sand cone density measurements (previously cliscussed). The samples were compacted in the specimen tubes after purging the tubes with argon gas. During the setup of each permeameter run, the permeameter was purged with argon, and during runs 5 through 8 , argon was allowed to bleed into the bubble tube to help reduce the amount of oxygen invading the system. Total porosity of the compacted materials was determined using methods described in Methods of Soil AnalysisPart 1 (1982). The total porosity was used to determine the pore volume of the specimens. 
The attenuation tests were conducted using a constant head permeameter constructed by Trautwein Soil Testing Equipment. The flow rate of solution through the test specimens was approximately $1.6 \mathrm{ft} /$ day $\left(5.65 \times 10^{-4} \mathrm{~cm} / \mathrm{sec}\right)$, which is the approximate flow rate in the aquifer as determined by TriHydro Corporation. Flow rates in the constant head permeameter were controlled by varying the head difference across the specimens using the elevation differences between a bubble tube located in the solution reservoir and the outflow from the base of the permeameter. Five permeameter runs were conducted for the contaminated ground water/ uncontaminated aquifer material tests, and three runs were conducted for the uncontaminated ground water/contaminated aquifer material tests. Each test consisted of collecting 5 pore volumes of ground water from the specimen. After about 0.5 pore volume of ground water had exited the permeameter, a sample of the effluent water was collected every $15 \mathrm{ml}$ until 2 pore volumes of solution had been collected. A single sample of the effluent was collected following the permeation of the third, fourth, and fifth pore volumes. The samples were tested for $\mathrm{pH}, \mathrm{EC}$, and Eh soon after collection. The head space of each sample was purged with argon, and a portion of each sample was acidified and refrigerated for $\mathrm{NH}_{4}{ }^{+1}$ and nitrate $\left(\mathrm{NO}_{3}{ }^{-1}\right)$ analysis.

The attenuation tests were conducted using two scenarios. In the first scenario, the uncontaminated aquifer material (MW1) was placed in the sample container using the procedure explained previously. Following compaction, the material was saturated with water from the MW1 ground water sample. The saturated sample was then leached with the contaminated water collected from well MW6. As noted previously, 5 pore volumes of water were collected from the outflow. In the second scenario, the tests were conducted using the same conditions except the contaminated aquifer material (MW6) was leached with the uncontaminated water (MW1).

The analytical work was conducted by an experienced analyst using formal procedures for analytical quality control. The quality control system included: the use of tuning and calibration checks on equipment, duplicate analysis every 10 samples, spiked and blank sample analysis every 10 samples, the use of standard checks, the use of certified standards, limited-access laboratories, and complete documentation of every aspect of the work in notebooks. 


\section{RESULTS AND DISCUSSION}

\section{Tests - Uncontaminated Aquifer Material and Ammonium Contaminated Ground Water}

The pore volume associated with the aquifer was estimated using the particle density calculated in the laboratory and the bulk density determined in the field using sand cone testing equipment. The particle densities for samples MW1 and MW6 were $2.65 \mathrm{~g} / \mathrm{cm}^{3}$ and $2.63 \mathrm{~g} / \mathrm{cm}^{3}$, respectively. A particle density of $2.65 \mathrm{~g} / \mathrm{cm}^{3}$ and a field bulk density of $2.0 \mathrm{~g} / \mathrm{cm}^{3}$ were used to calculate the pore volume of about $27 \%$ that was used to determine the amount of solution needed to flow through the aquifer materials during each run.

A series of five runs were conducted with very similar results from each. In these tests, MW6 water, which contains high levels of $\mathrm{NH}_{4}{ }^{+1}$, was used as a permeate for the MW1 aquifer material, which was not previously influenced by the $\mathrm{NH}_{4}{ }^{+1}$ contaminated ground water. The data collected during these tests are shown in Figures 1 through 5.

The nitrate levels of solutions exiting the aquifer material were relatively constant at low concentrations throughout the 5 pore volume flow period. Therefore, it appears that very little $\mathrm{NH}_{4}{ }^{+1}$ is converted to $\mathrm{NO}_{3}^{-1}$ during the leaching process. The gradual increase in $\mathrm{NH}_{4}{ }^{+1}$ levels in the effluent as the high $\mathrm{NH}_{4}^{+1}$ ground water is leached through the aquifer material probably results from the diffusion, hydrodynamic dispersion, and soil sorption processes taking place in the system. The cation exchange capacity of the MW1 material is low at about $4 \mathrm{meq} / 100 \mathrm{~g}$ of soil. As a result, the aquifer material is able to hold only small amounts of $\mathrm{NH}_{4}{ }^{+1}$. Therefore, diffusion and dispersion are thought to be the most important contributors to the noted dilution.

The $\mathrm{NH}_{4}{ }^{+1}$ level of the MW6 water was initially $40.7 \mathrm{mg} / \mathrm{L}$, and at the end of the run the MW6 water from the same container had $34.4 \mathrm{mg} / \mathrm{L}$ of $\mathrm{NH}_{4}{ }^{+1}$. The change is suspected to be associated with sorption of $\mathrm{NH}_{4}{ }^{+1}$ to Fe-precipitates or other amorphous materials. Therefore, as the $\mathrm{NH}_{4}{ }^{+1}$ contaminated ground water moves through the uncontaminated zone, a gradual decline in the levels of $\mathrm{NH}_{4}{ }^{+1}$ found in solution would be expected. However, this assumption does not give consideration to the conversion of $\mathrm{NH}_{4}{ }^{+1}$ to $\mathrm{NO}_{3}^{-1}$ due to the nitrification processes that may occur at some point in the ground water system.

An interesting aspect of the chemistry of this system is that the $\mathrm{pH}$ and Eh of the effluent from the column are relatively constant throughout the run. The $\mathrm{pH}$ ranged from about 8.14 to 7.82 , and the Eh varied from about $+224 \mathrm{mv}$ to $+180 \mathrm{mv}$. The $\mathrm{pH}$ of the inflow appeared to be similar to the $\mathrm{pH}$ of the outflow. However, the Eh of the inflow appeared to be poised by the aquifer material to a higher level. For example, the Eh of the inflow for Test 5 was $-152 \mathrm{mv}$ and 


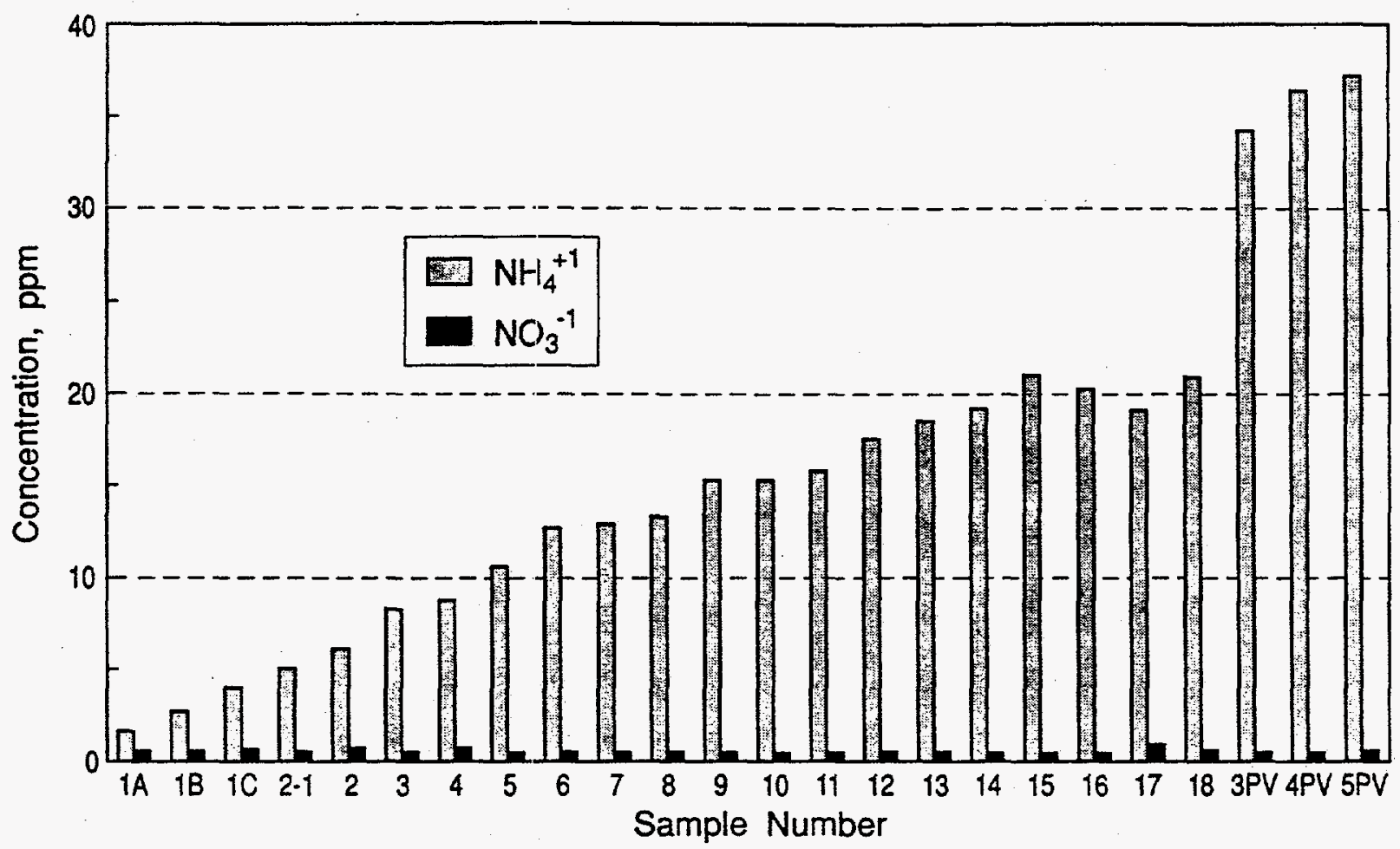

Figure 1. The Levels of Ammonium and Nitrate in Leachate from MW1 Aquifer Material Leached with MW6 Ground Water for Run 1

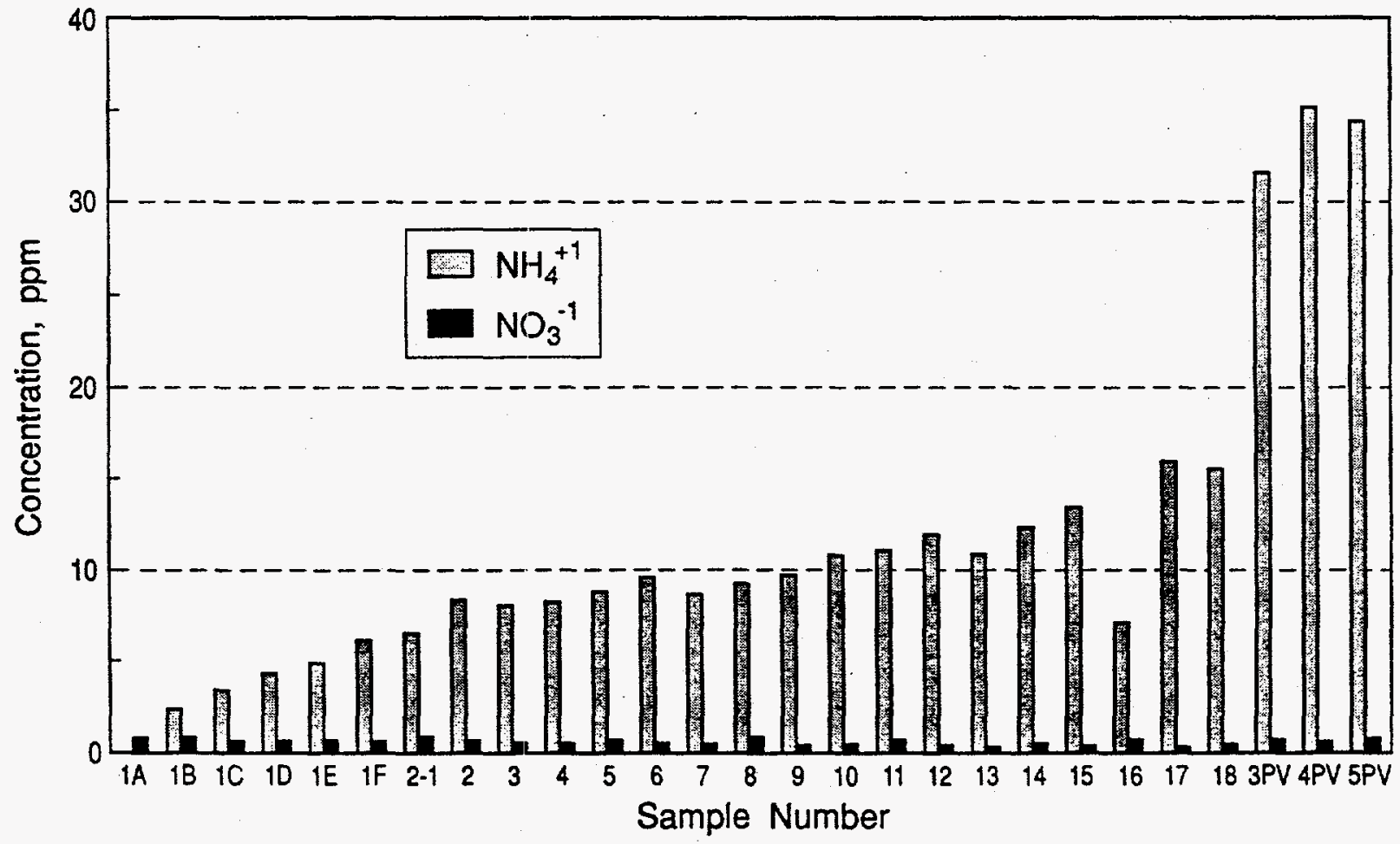

Figure 2. The Levels of Ammonium and Nitrate in Leachate from MW1 Aquifer Material Leached with MW6 Ground Water for Run 2 


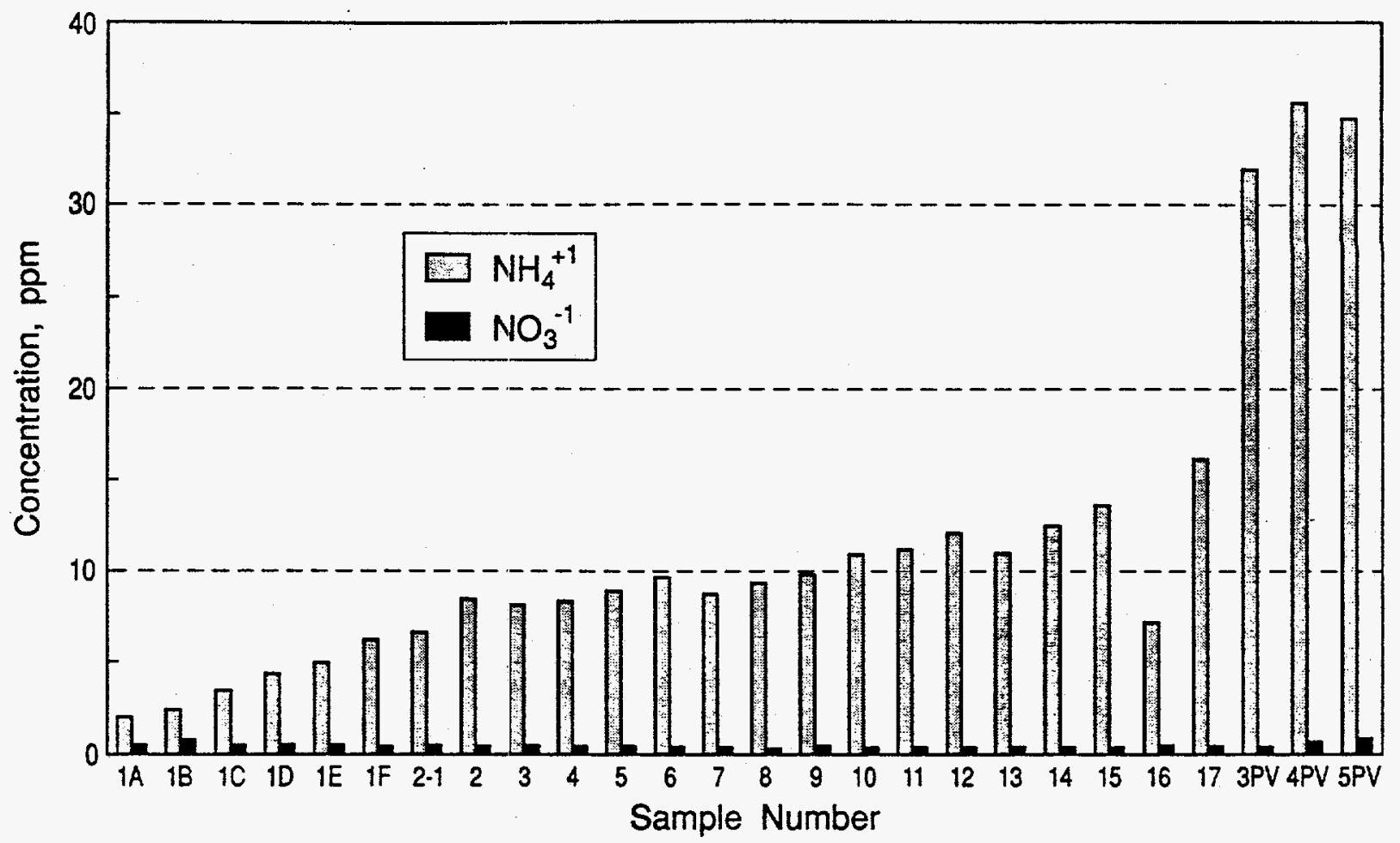

Figure 3. The Levels of Ammonium and Nitrate in Leachate from MW1 Aquifer Material Leached with MW6 Ground Water for Run 3

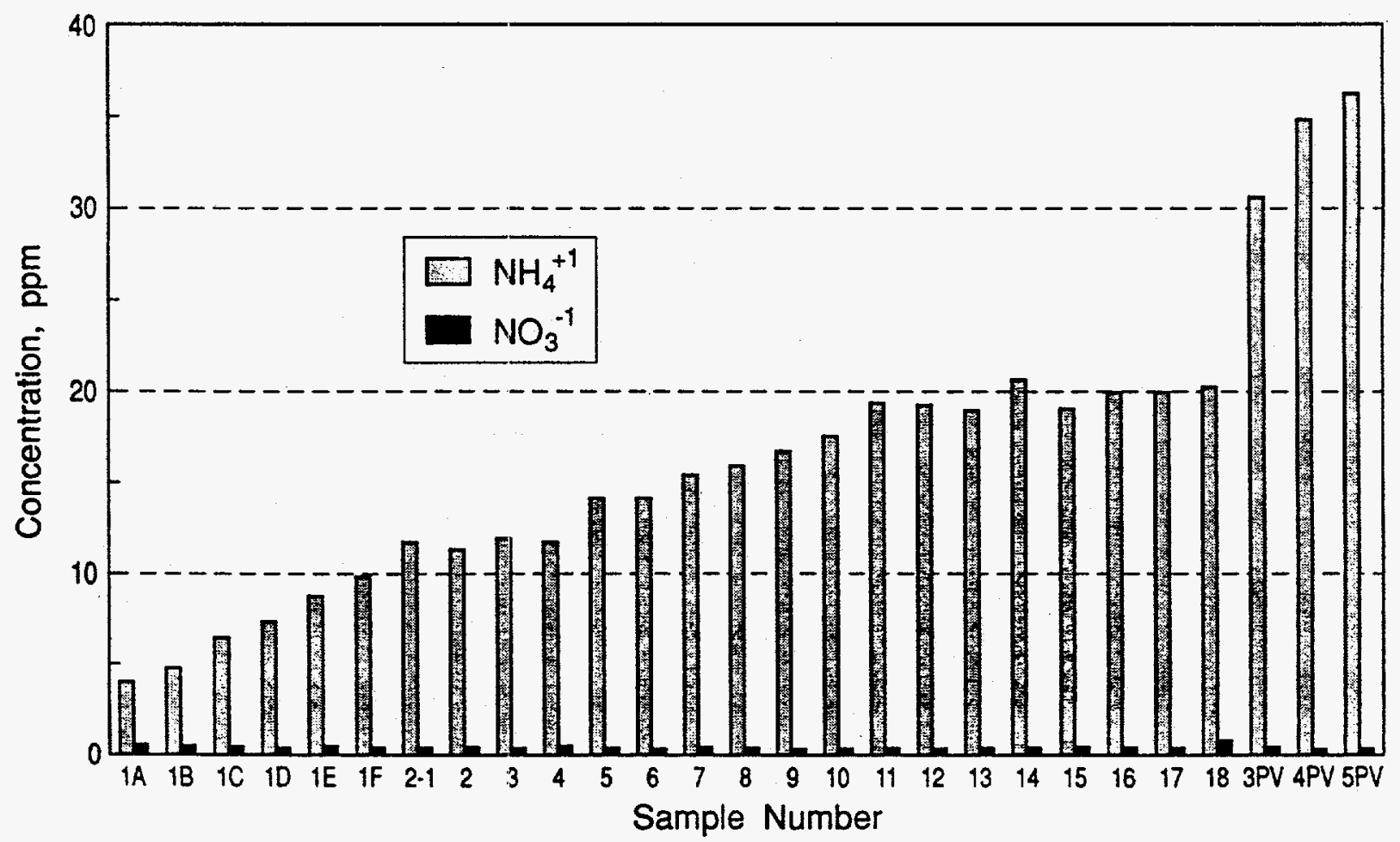

Figure 4. The Levels of Ammonium and Nitrate in Leachate from MW1 Aquifer Material Leached with MW6 Ground Water for Run 4 


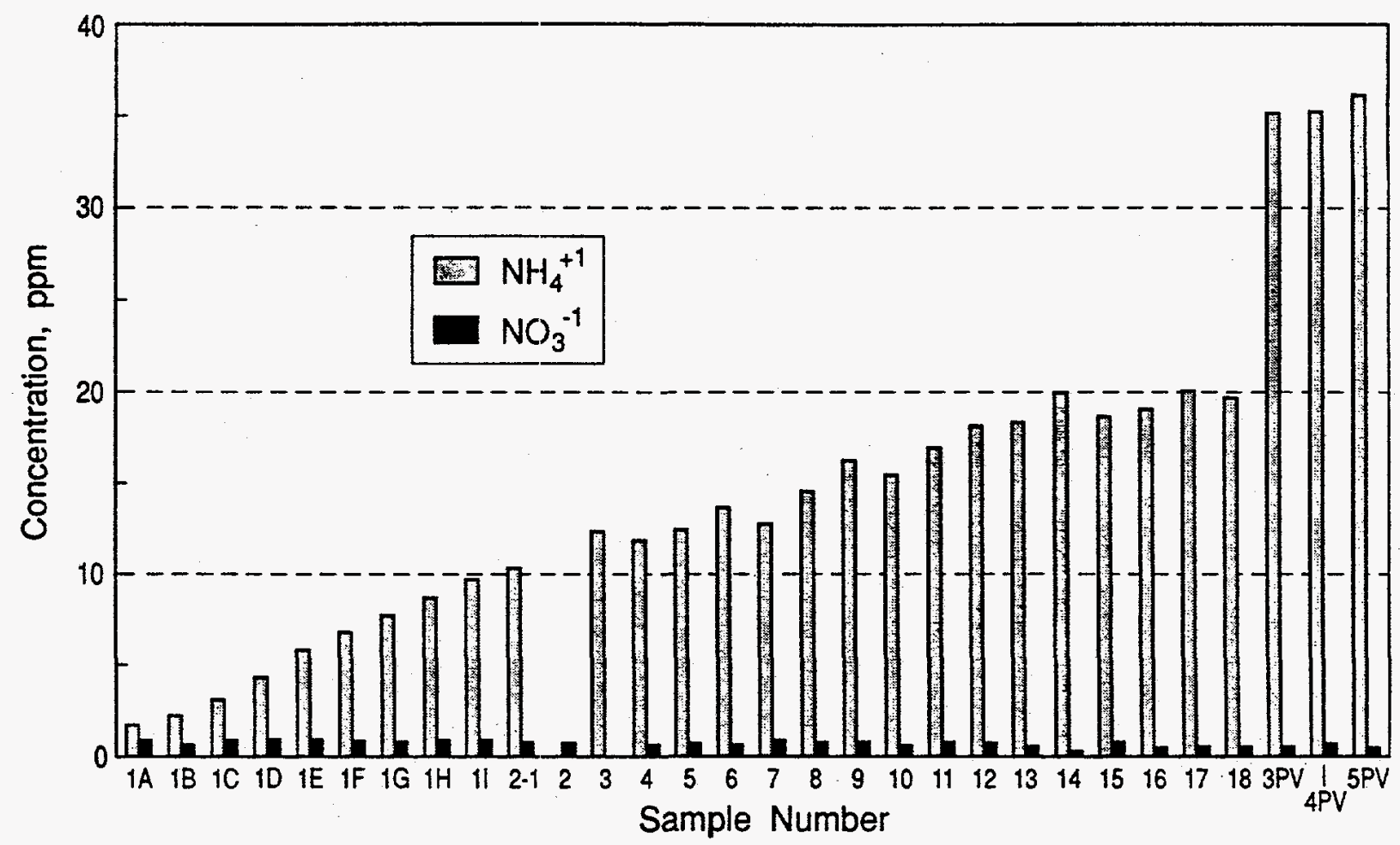

Figure 5. The Levels of Ammonium and Nitrate in Leachate from MW1 Aquifer Material Leached with MW6 Ground Water for Run 5

the effluent had Eh values of about $+190 \mathrm{mv}$. The Eh values of all the effluent samples from all runs using MW6 water with MW1 aquifer material were comparable at the $+224 \mathrm{mv}$ to $+180 \mathrm{mv}$ levels. This was true even with substantial efforts to keep air from influencing the system.

A possible cause of this phenomenon may be associated with the redox couple $\mathrm{Fe}^{+2} \Leftrightarrow$ $\mathrm{Fe}^{+3}+\mathrm{e}^{-1}$, which is thought to be important in this ground water system since with time Fe-oxides precipitate from the contaminated ground water when exposed to air. $\mathrm{Fe}^{+2}$ is thought to be in the ground water at rather high levels due to the incorporation of the sugar beet sludge into the aquifer, causing reducing conditions with measured $\mathrm{Eh}$ values of about $-200 \mathrm{mv}$. As a result, the sludge material undergoes anaerobic decomposition, causing the release of nitrogen in the form of $\mathrm{NH}_{4}^{+1}$. At the same time, iron compounds present in the sugar beet sludge or resulting from the breakdown of minerals present in the aquifer are becoming soluble as $\mathrm{Fe}^{+2}$.

As stated previously, measured Eh values of the uncontaminated ground water are poised at about $+200 \mathrm{mv}$ and at a $\mathrm{pH}$ near 8 . Under these conditions, the $\mathrm{Fe}^{+2}$ tends to oxidize, forming $\mathrm{Fe}^{+3}$ compounds. In comparison, the oxidation potential of the $\mathrm{Fe}$ couple is about $-200 \mathrm{mv}$ at $\mathrm{pH}$ 8 (This will vary, however, depending on the complexity of the system), and the oxidation potential of the $\mathrm{NH}_{4}{ }^{+1}$ couple is $+260 \mathrm{mv}$ at $\mathrm{pH} 8$. Therefore, the oxidation of $\mathrm{Fe}^{+2}$ may tend to promote the reduction of nitrogen. If a considerable amount of $\mathrm{Fe}^{+2}$ exists in the system, the tendency may be to maintain nitrogen in the $\mathrm{NH}_{4}{ }^{+1}$ form and to poise the system at a specific Eh 
value until the $\mathrm{Fe}^{+2}$ becomes oxidized. After $\mathrm{Fe}^{+2}$ is depleted from solution, $\mathrm{NH}_{4}^{+1}$ will begin to convert to $\mathrm{NO}_{3}{ }^{-1}$. However, this system may have much more complexity, as other redox couples are probably involved. The Eh continued to increase with time for the MW6 water stored under argon and at about $4^{\circ} \mathrm{C}$. However, several runs were conducted with MW6 water having Eh values of about $+150 \mathrm{mv}$ without showing any differences in results compared to water with initial Eh values of $-150 \mathrm{mv}$. Regardless of the redox condition of the leaching solution, the Eh of the outflow seemed to be poised at about +180 to $+200 \mathrm{mv}$. Additional work would have to be done to thoroughly understand the chemistry of this system.

\section{Tests - Ammonium Contaminated Aquifer Material and Uncontaminated Ground Water}

The concentrations of $\mathrm{NH}_{4}^{-1}$ and $\mathrm{NO}_{3}^{-1}$ leached from the contaminated aquifer materials (MW6) using MW1 ground water as the leaching solution are shown in Figures 6 through 8 . The data shown in Figure 6 indicate that much of the $\mathrm{NH}_{4}{ }^{+1}$ present in the aquifer material was converted to $\mathrm{NO}_{3}{ }^{-1}$ either prior to or during the run. Similar results were obtained for Runs 7 and 8 , which were done using a different sample of contaminated material (Figures 7 and 8). The only difference observed between Runs 7 and 8 and the data shown in Figure 6 for Run 6 was that $\mathrm{NH}_{4}{ }^{+1}$ levels were in the range of $5 \mathrm{mg} / \mathrm{L}$, compared to about $1.5 \mathrm{mg} / \mathrm{L}$ found in Run 6 . The differences found in $\mathrm{NH}_{4}^{+1}$ could be associated with sorption on Fe-compounds. Initially it was thought that the $\mathrm{NH}_{4}^{+1}$ was converted to $\mathrm{NO}_{3}^{-1}$ in the contaminated aquifer materials (MW6) during sample storage or during sample setup. The rapid breakthrough of the $\mathrm{NO}_{3}{ }^{-1}$ in the leachate would definitely support this conclusion. However, a solution sample collected from the original sample of MW6 indicated that the $\mathrm{NH}_{4}{ }^{+1}$ did not convert to $\mathrm{NO}_{3}^{-1}$ during storage but was converted either during the setup of the sample as a result of contamination of air into the system followed by nitrification or during permeation of the uncontaminated aquifer material from the promotion of nitrification by a process operating under the conditions of the system. Additional testing would have to be done to determine how the $\mathrm{NO}_{3}{ }^{-1}$ is formed in this system.

There appears to be a logical means for the conversion of $\mathrm{NH}_{4}{ }^{+1}$ to $\mathrm{NO}_{3}{ }^{-1}$ in the sample core during the leaching process. As discussed previously, if $\mathrm{Fe}^{+2}$ is present in the system with $\mathrm{NH}_{4}^{+1}$, it will oxidize before the oxidation of $\mathrm{NH}_{4}^{+1}$, preventing or retarding the oxidation of $\mathrm{NH}_{4}^{+1}$ to $\mathrm{NO}_{3}{ }^{-1}$. However, once the $\mathrm{Fe}^{+2}$ has been depleted, the $\mathrm{NH}_{4}^{+1}$ present in the system is allowed to convert to $\mathrm{NO}_{3}{ }^{-1}$. The depletion of the $\mathrm{Fe}^{+2}$ in the system can be caused by oxidation and possibly by dilution resulting from the addition of MW1 ground water, which contains very low levels of $\mathrm{Fe}^{+2}$, to the MW6 aquifer material.

The data presented in Figures 6 through 8 also show that the nitrogen present in the aquifer material is removed as leaching progresses. Initial $\mathrm{NH}_{4}^{+1}$ plus $\mathrm{NO}_{3}{ }^{-1}$ levels of about 20 $\mathrm{mg} / \mathrm{L}$ are reduced to less than $2 \mathrm{mg} / \mathrm{L}$ after 5 pore volumes of leaching. This supports the contention that the aquifer will become less contaminated with time following the removal or elimination of the source of contamination. 


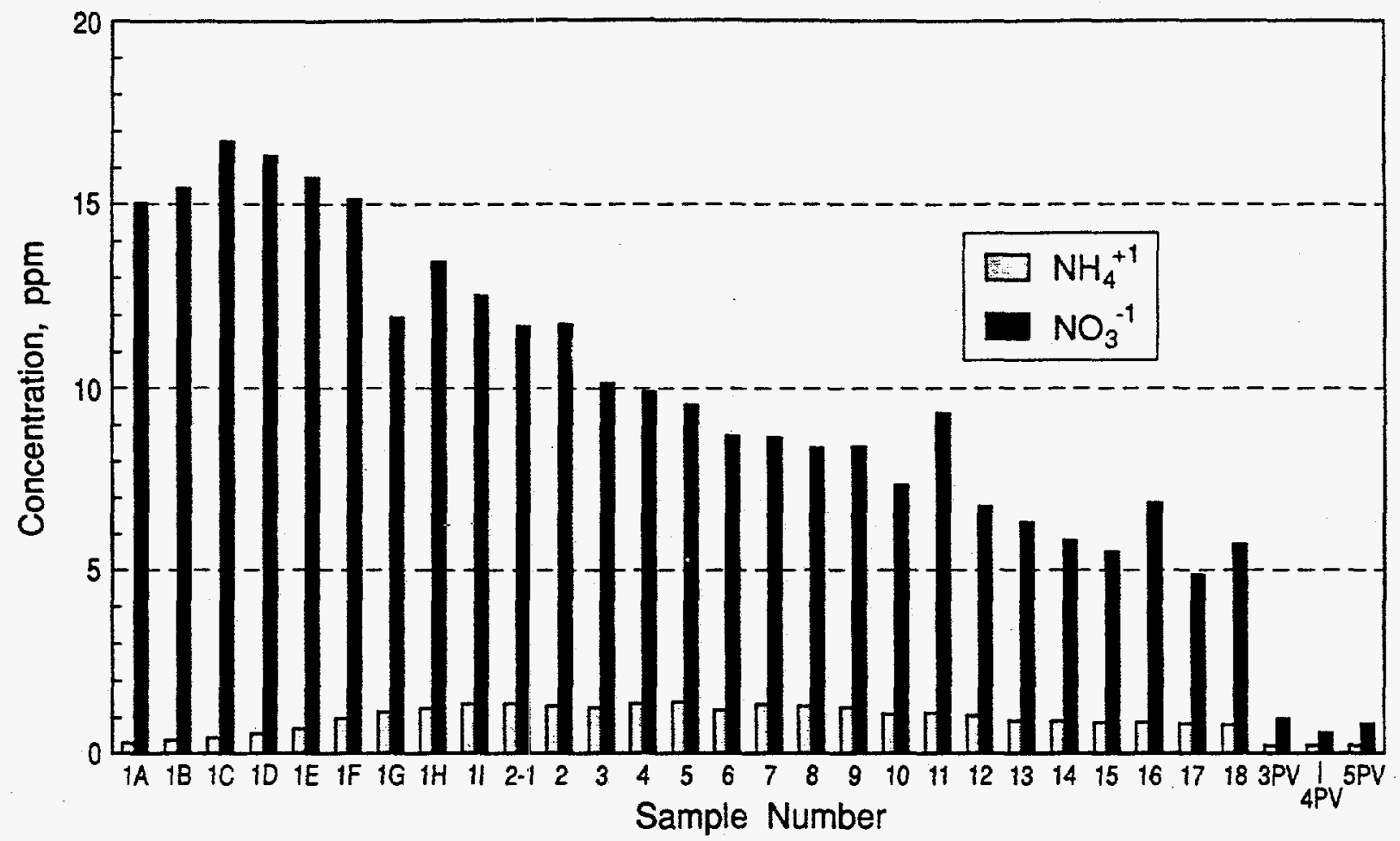

Figure 6. The Levels of Ammonium and Nitrate in Leachate from MW6 Aquifer Material Leached with MW1 Ground Water for Run 6

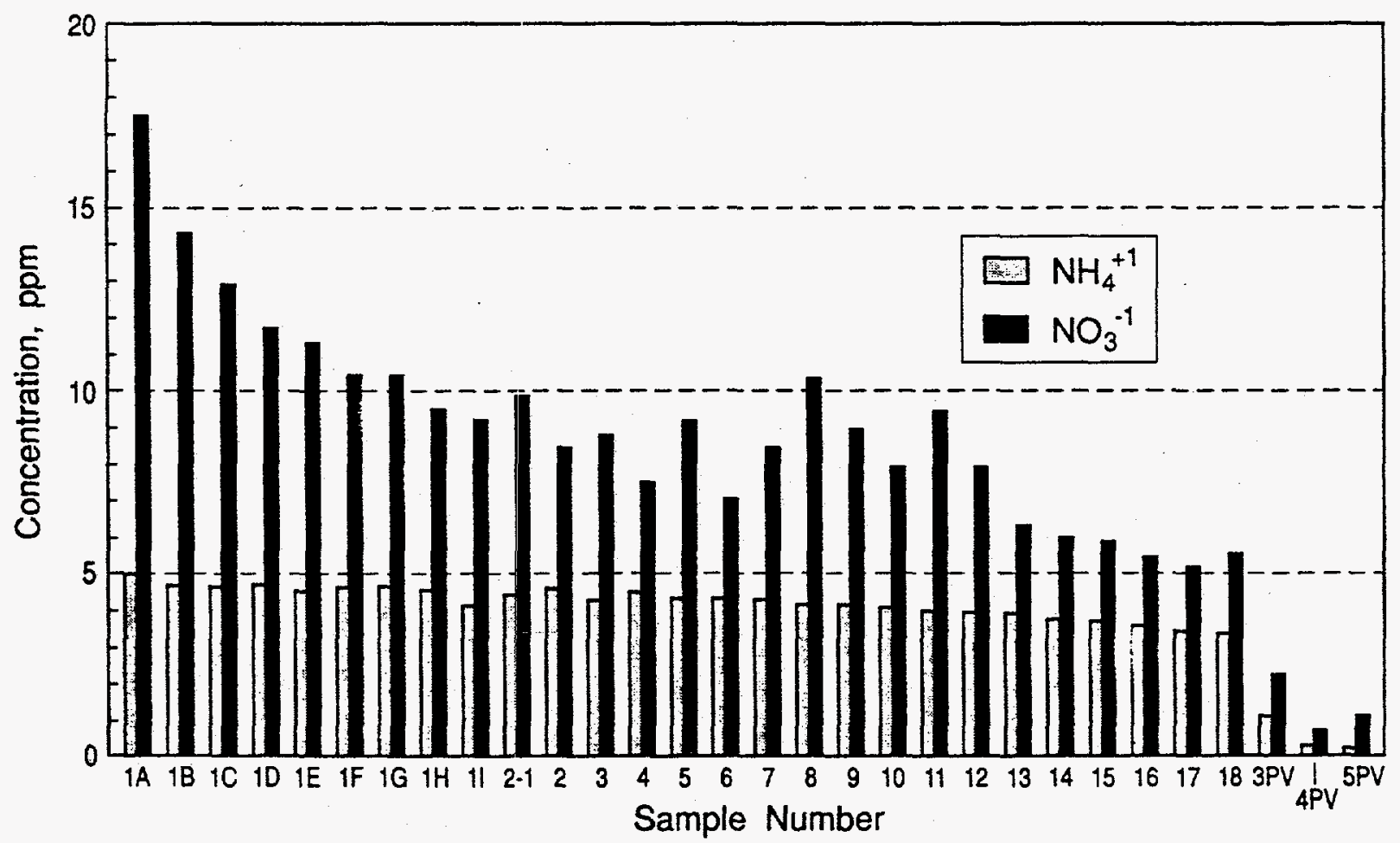

Figure 7. The Levels of Ammonium and Nitrate in Leachate from MW6 Aquifer Material Leached with MW1 Ground Water for Run 7 


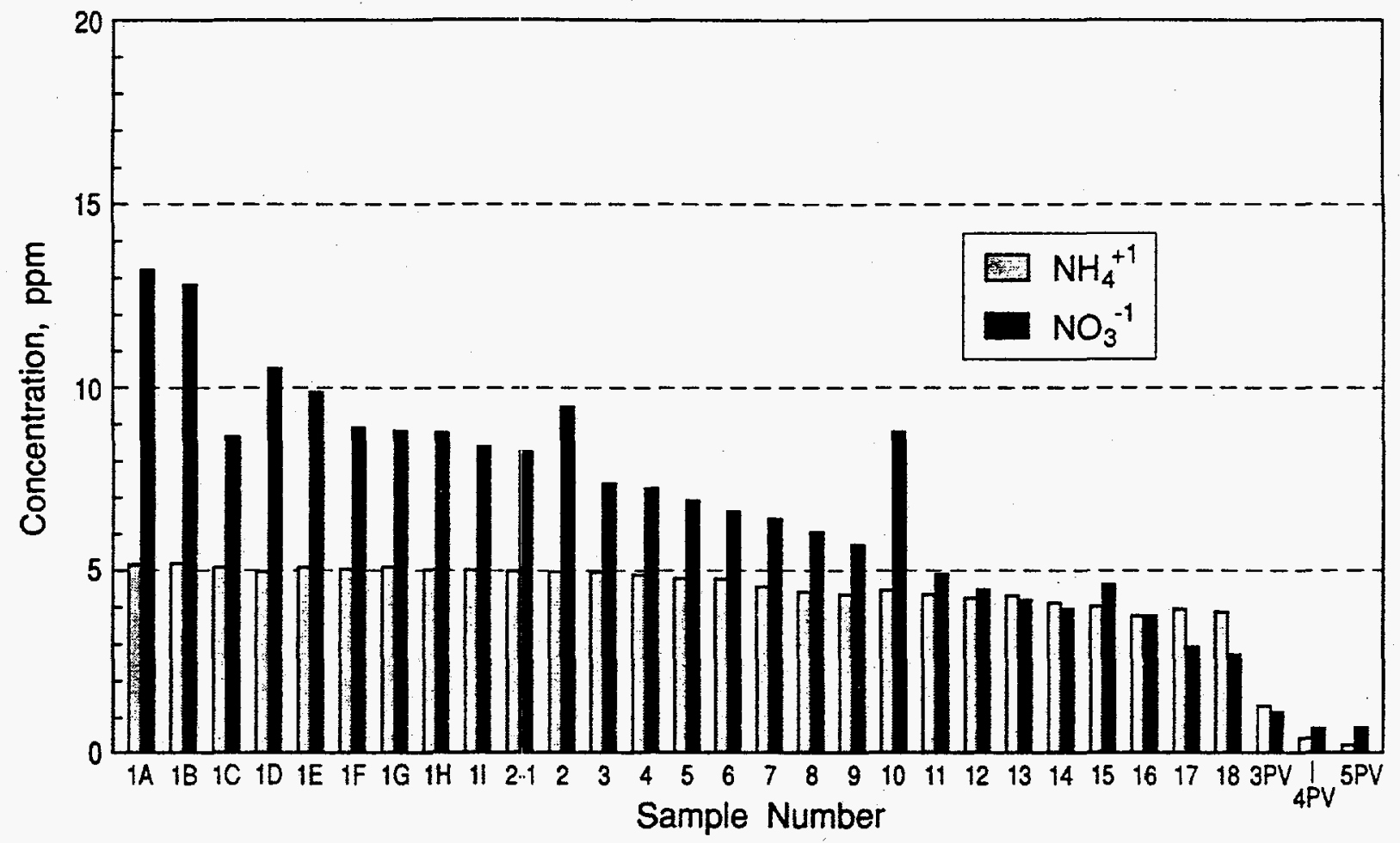

Figure 8. The Levels of Ammonium and Nitrate in Leachate from MW6 Aquifer Material Leached with MW1 Ground Water for Run 8

\section{CONCLUSIONS}

The data collected during the attenuation tests do provide an indication that the attenuation of $\mathrm{NH}_{4}{ }^{+1}$ in the ground water system will occur. In addition, the results show the redox condition of the site and the possible chemical reactions that are influencing the ground water quality.

The tests completed with MW1 aquifer material leached with MW6 ground water show that dilution of $\mathrm{NH}_{4}{ }^{+1}$ does occur at the front of the plume as it moves through the aquifer material (Figures 1 through 5). Apparently, the dilution is primarily a result of diffusion and hydrodynamic dispersion with some retardation due to electrostatic forces. In addition, the mixed system appears to have a redox condition poised at Eh values between +180 and $+200 \mathrm{mv}$ and $\mathrm{pH}$ values of about 7.9. This phenomenon may be caused by the $\mathrm{Fe}^{+2} \Leftrightarrow \mathrm{Fe}^{+3}+\mathrm{e}^{-1}$ couple. It is possible that this redox condition occurs at the fringes of the contamination plume.

The system of MW6 aquifer material leached with MW1 ground water used to evaluate removal of $\mathrm{NH}_{4}{ }^{+1}$ from the MW6 aquifer material had a poised redox condition of about $+180 \mathrm{mv}$ to $+200 \mathrm{mv}$. In addition, the relatively high levels of $\mathrm{NO}_{3}{ }^{-1}$ leached from the system could be due to either (1) the inadvertent incorporation of air into the system during sample setup, promoting 
nitrification, or (2) the depletion of $\mathrm{Fe}^{+2}$ concentrations, allowing nitrification to occur. Additional studies would be required to determine the phenomenon causing the formation of $\mathrm{NO}_{3}^{-1}$ in this system. 


\section{REFERENCES}

Methods of Soil Analysis-Part 1, Physical and Minerological Methods, 2nd ed., 1982 Agronomy Monograph 9. Page, A. L., Ed. ASA and SSSA, Madison, WI. 
APPENDIX A

TABLES 


\begin{tabular}{|c|c|c|c|c|c|}
\hline \multicolumn{2}{|c|}{ Table 1. Run 1 (5/4/95) - MW6 Ground Water with MW1 Aquifer Material } \\
\hline Sample & $\mathrm{pH}$ & $\mathrm{EC}$ & $\mathrm{Eh}$ & $\mathrm{NH}_{4}{ }^{+1}$ & $\mathrm{NO}_{3}{ }^{-1}$ \\
\hline & $\mathrm{Su}$ & $\mathrm{mS} / \mathrm{cm}$ & $\mathrm{mV}$ & $\mathrm{ppm}$ & $\mathrm{ppm}$ \\
\hline $1-\mathrm{A}$ & 7.94 & & 142 & 1.64 & 0.6 \\
\hline $1-\mathrm{B}$ & 7.94 & & 150 & 2.73 & 0.59 \\
\hline $1-\mathrm{C}$ & 7.97 & & 146 & 4.01 & 0.66 \\
\hline $2-1$ & 7.85 & & 124 & 5.05 & 0.54 \\
\hline 2 & 7.94 & & 146 & 6.12 & 0.74 \\
\hline 3 & 7.9 & & 152 & 8.29 & 0.51 \\
\hline 4 & 7.89 & & 158 & 8.78 & 0.73 \\
\hline 5 & 7.92 & & 164 & 10.6 & 0.48 \\
\hline 6 & 7.91 & & 160 & 12.7 & 0.53 \\
\hline 7 & 7.89 & & 150 & 12.9 & 0.5 \\
\hline 8 & 7.89 & & 164 & 13.3 & 0.53 \\
\hline 9 & 7.87 & & 163 & 15.3 & 0.48 \\
\hline 10 & 7.86 & & 165 & 15.3 & 0.47 \\
\hline 11 & 7.87 & & 160 & 15.8 & 0.48 \\
\hline 12 & 7.89 & & 162 & 17.5 & 0.52 \\
\hline 13 & 7.85 & & 165 & 18.5 & 0.53 \\
\hline 14 & 7.89 & & 165 & 19.2 & 0.46 \\
\hline 15 & 7.87 & & 162 & 21 & 0.47 \\
\hline 16 & 7.88 & & 163 & 20.2 & 0.45 \\
\hline 17 & 7.85 & & 173 & 19.1 & 0.9 \\
\hline 18 & 7.87 & & 172 & 20.9 & 0.6 \\
\hline $3 \mathrm{PV}$ & 7.84 & & 205 & 34.2 & 0.48 \\
\hline $4 \mathrm{PV}$ & - & - & 36.4 & 0.48 \\
\hline $5 \mathrm{PV}$ & - & & & 37.2 & 0.6 \\
\hline
\end{tabular}




\begin{tabular}{|c|c|c|c|c|c|c|}
\hline Sample & $\mathrm{pH}$ & EC & Eh & 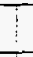 & $\mathrm{NH}_{4}^{+1}$ & $\mathrm{NO}_{3}^{-1}$ \\
\hline & su & $\mathrm{mS} / \mathrm{cm}$ & $\mathrm{mv}$ & $\vdots$ & $\mathrm{ppm}$ & $\mathrm{ppm}$ \\
\hline $1 \mathrm{~A}$ & . & - & - & i & - & 0.8 \\
\hline $1 B$ & 8.02 & 1.3 & 224 & & 2.38 & 0.84 \\
\hline $1 \mathrm{C}$ & 8.04 & 1.36 & 194 & & 3.42 & 0.64 \\
\hline 10 & 8.07 & 1.42 & 194 & & 4.32 & 0.63 \\
\hline $1 E$ & 7.99 & 1.36 & 4.9 & & 4.9 & 0.7 \\
\hline $1 F$ & 8.05 & 1.58 & 183 & & 6.14 & 0.62 \\
\hline $2-1$ & 8.14 & 1.56 & 187 & & 6.55 & 0.88 \\
\hline 2 & 8.13 & 1.51 & 190 & & 8.32 & 0.67 \\
\hline 3 & 7.96 & 1.29 & 178 & & 8.02 & 0.56 \\
\hline 4 & 8.03 & 1.31 & 184 & & 8.2 & 0.52 \\
\hline 5 & 8.06 & 1.31 & 180 & & 8.76 & 0.69 \\
\hline 6 & 7.98 & 1.29 & 214 & & 9.51 & 0.55 \\
\hline 7 & 7.98 & 1.3 & 214 & ! & 8.62 & 0.48 \\
\hline 8 & 7.97 & 1.36 & 214 & & 9.2 & 0.87 \\
\hline 9 & 8.04 & 1.33 & 213 & & 9.66 & 0.41 \\
\hline 10 & 8.05 & 1.37 & 204 & 1 & 10.75 & 0.48 \\
\hline 11 & 7.86 & 1.3 & 212 & & 11 & 0.69 \\
\hline 12 & 7.93 & 1.28 & 204 & 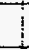 & 11.9 & 0.42 \\
\hline 13 & 7.97 & 1.3 & 200 & & 10.8 & 0.31 \\
\hline 14 & 7.95 & 1.32 & 214 & $T$ & 12.3 & 0.5 \\
\hline 15 & 8.01 & 1.34 & 212 & & 13.4 & 0.38 \\
\hline 16 & 7.94 & 1.33 & 214 & & 7.1 & 0.69 \\
\hline 17 & 8.01 & 1.33 & 213 & 1 & 15.9 & 0.32 \\
\hline 18 & 7.92 & 1.38 & 214 & & 15.5 & 0.47 \\
\hline PV-3 & 7.82 & 1.52 & 180 & & 31.5 & 0.72 \\
\hline PV-4 & 7.84 & 1.56 & 207 & 1 & 35.1 & 0.61 \\
\hline PV-5 & 7.84 & 1.56 & 208 & 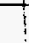 & 34.3 & 0.78 \\
\hline
\end{tabular}




\begin{tabular}{|c|c|c|c|c|c|}
\hline Sample & $\mathrm{pH}$ & EC & Eh & $\mathrm{NH}_{4}^{+1}$ & $\mathrm{NO}_{3}^{-1}$ \\
\hline & su & $\mathrm{mS} / \mathrm{cm}$ & $\mathrm{mv}$ & $\mathrm{ppm}$ & $\mathrm{ppm}$ \\
\hline $1-A$ & $8 . \overline{02}$ & 1.29 & 186 & 1.99 & 0.51 \\
\hline $1-B$ & 7.95 & 1.31 & 178 & 2.38 & 0.78 \\
\hline $1-C$ & 7.84 & 1.29 & 182 & 3.42 & 0.5 \\
\hline $1-D$ & 7.83 & 1.31 & 183 & 4.32 & 0.53 \\
\hline $1-E$ & 7.81 & 1.33 & 189 & 4.9 & 0.51 \\
\hline $1-F$ & 7.85 & 1.33 & 188 & 6.14 & 0.44 \\
\hline $2-1$ & 7.85 & 1.32 & 180 & 6.55 & 0.5 \\
\hline 2 & 7.89 & 1.35 & 189 & 8.32 & 0.44 \\
\hline 3 & 7.96 & 1.33 & 179 & 8.02 & 0.48 \\
\hline 4 & 8 & 1.35 & 177 & 8.2 & 0.43 \\
\hline 5 & 7.85 & 1.35 & 180 & 8.76 & 0.43 \\
\hline 6 & 7.87 & 1.35 & 184 & 9.51 & 0.41 \\
\hline 7 & 7.92 & 1.36 & 184 & 8.62 & 0.39 \\
\hline 8 & 7.9 & 1.38 & 184 & 9.2 & 0.31 \\
\hline 9 & 7.95 & 1.37 & 186 & 9.66 & 0.45 \\
\hline 10 & 7.95 & 1.37 & 182 & 10.75 & 0.37 \\
\hline 11 & 7.84 & 1.38 & 183 & 11 & 0.39 \\
\hline 12 & 7.82 & 1.38 & 183 & 11.9 & 0.38 \\
\hline 13 & 7.88 & 1.43 & 180 & 10.8 & 0.4 \\
\hline 14 & 7.87 & 1.4 & 184 & 12.3 & 0.38 \\
\hline 15 & 7.86 & 1.42 & 175 & 13.4 & 0.38 \\
\hline 16 & 7.83 & 1.44 & 178 & 7.1 & 0.48 \\
\hline 17 & 7.89 & 1.41 & 181 & 15.9 & 0.44 \\
\hline PV-3 & 7.95 & 1.5 & 201 & 31.5 & 0.41 \\
\hline PV-4 & 7.77 & 1.48 & 199 & 35.1 & 0.67 \\
\hline \multirow[t]{3}{*}{ PV-5 } & 7.94 & 1.5 & 192 & 34.3 & 0.85 \\
\hline & & 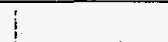 & 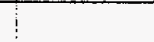 & & \\
\hline & & & & & \\
\hline
\end{tabular}




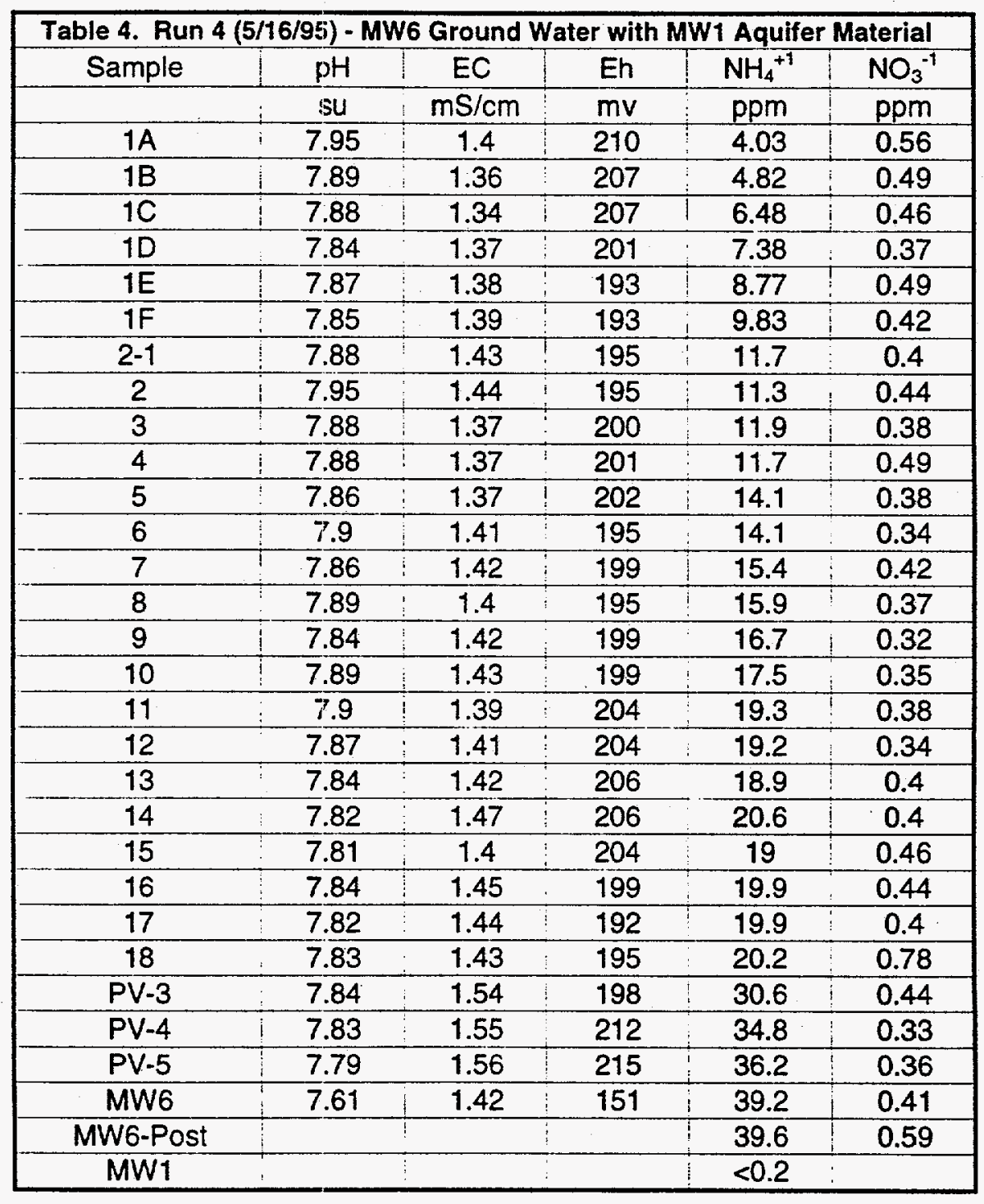




\begin{tabular}{|c|c|c|c|c|c|}
\hline Sample & $\mathrm{pH}$ & EC & $\mathrm{Eh}$ & $\mathrm{NH}_{4}^{+1}$ & $\mathrm{NO}_{3}{ }^{-1}$ \\
\hline & su & $\mathrm{mS} / \mathrm{cm}$ & $m v$ & $\mathrm{ppm}$ & $\mathrm{ppm}$ \\
\hline $1 \mathrm{~A}$ & $?$ & 1.32 & 212 & 1.69 & 0.88 \\
\hline 1B & 7.96 & 1.32 & 201 & 2.21 & 0.63 \\
\hline $1 \mathrm{C}$ & 7.83 & 1.34 & 209 & 3.1 & 0.87 \\
\hline 10 & 7.82 & 1.33 & 200 & 4.32 & 0.91 \\
\hline $1 E$ & 7.84 & 1.37 & 192 & 5.82 & 0.89 \\
\hline IF & 7.83 & 1.37 & 192 & 6.79 & 0.83 \\
\hline $1 G$ & 7.79 & 1.4 & 193 & 7.72 & 0.78 \\
\hline $1 \mathrm{H}$ & 7.85 & 1.41 & 199 & 8.67 & 0.86 \\
\hline 11 & 7.8 & 1.37 & 200 & 9.68 & 0.88 \\
\hline $2-1$ & 7.76 & 1.39 & 200 & 10.3 & 0.76 \\
\hline 2 & 7.82 & 1.41 & 199 & & 0.71 \\
\hline 3 & 7.83 & 1.37 & 197 & 12.3 & 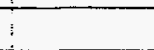 \\
\hline 4 & 7.81 & 1.4 & 198 & 11.8 & 0.63 \\
\hline 5 & 7.79 & 1.43 & 200 & 12.4 & 0.7 \\
\hline 6 & 7.77 & 1.4 & 199 & 13.6 & 0.61 \\
\hline 7 & 7.75 & 1.44 & 197 & 12.7 & 0.86 \\
\hline 8 & 7.75 & 1.42 & 194 & 14.5 & 0.74 \\
\hline 9 & 7.75 & 1.48 & 180 & 16.2 & 0.75 \\
\hline 10 & 7.79 & 1.4 & 193 & 15.4 & 0.59 \\
\hline 11 & 7.71 & 1.44 & 187 & 16.9 & 0.76 \\
\hline 12 & 7.77 & 1.42 & 194 & 18.1 & 0.72 \\
\hline 13 & 7.73 & 1.46 & 195 & 18.3 & 0.55 \\
\hline 14 & 7.72 & 1.44 & 197 & 19.9 & 0.29 \\
\hline 15 & 7.74 & 1.47 & 181 & 18.6 & 0.76 \\
\hline 16 & 7.72 & 1.45 & 189 & 19 & 0.48 \\
\hline 17 & 7.73 & 1.44 & 191 & 20 & 0.52 \\
\hline 18 & 7.75 & 1.48 & 192 & 19.6 & 0.51 \\
\hline PV-3 & 7.62 & 1.53 & 198 & 35.1 & 0.53 \\
\hline PV-4 & 7.72 & 1.5 & 200 & 35.2 & 0.67 \\
\hline PV-5 & 7.69 & 1.63 & 190 & 36.1 & 0.48 \\
\hline (fresh water) & 7.45 & 1.66 & -151.7 & & \\
\hline & \multicolumn{5}{|c|}{ (within the first 30 minutes the sample turned orange) } \\
\hline MW6 Pre & 7.45 & 1.66 & -151.7 & 45.2 & 4 \\
\hline MW1-Pre & 7.42 & 1.1 & 239.5 & $<0.2$ & 7 \\
\hline MW6-Post & & & & & 0.35 \\
\hline MW1-Post & & & & & 0.52 \\
\hline Res - Post & & & & 45 & 0.54 \\
\hline
\end{tabular}




\begin{tabular}{|c|c|c|c|c|c|}
\hline Sample & $\mathrm{pH}$ & $E C$ & Eh & $\mathrm{NH}_{4}{ }^{+1}$ & $\mathrm{NO}_{3}^{-1}$ \\
\hline & su & $\mathrm{mS} / \mathrm{cm}$ & $\mathrm{mv}$ & $\mathrm{ppm}$ & $\mathrm{ppm}$ \\
\hline $1 \mathrm{~A}$ & 7.95 & 1.35 & 172 & 0.28 & 15 \\
\hline 1B & 7.95 & 1.36 & 164 & 0.35 & 15.4 \\
\hline $1 \mathrm{C}$ & 7.94 & 1.44 & 166 & 0.41 & 16.7 \\
\hline 1D & 7.94 & 1.37 & 170 & 0.52 & 16.3 \\
\hline $1 E$ & 7.88 & 1.35 & 170 & 0.65 & 15.7 \\
\hline $1 \mathrm{~F}$ & 7.9 & 1.35 & $17 \overline{3}$ & 0.94 & 15.1 \\
\hline $1 G$ & 7.89 & 1.36 & 178 & 1.12 & 11.9 \\
\hline $1 \mathrm{H}$ & 7.87 & 1.32 & 182 & 1.22 & 13.4 \\
\hline 11 & 7.91 & 1.35 & 174 & 1.34 & 12.5 \\
\hline $2-1$ & 7.93 & 1.28 & 177 & 1.35 & 11.65 \\
\hline 2 & 7.9 & 1.29 & 183 & 1.28 & 11.7 \\
\hline 3 & 7.9 & 1.28 & 175 & 1.24 & 10.1 \\
\hline 4 & 7.92 & 1.27 & 164 & 1.35 & 9.87 \\
\hline 5 & 7.91 & 1.31 & 169 & 1.4 & 9.52 \\
\hline 6 & 7.95 & 1.23 & 174 & 1.17 & 8.66 \\
\hline 7 & 7.9 & 1.22 & 171 & 1.33 & 8.62 \\
\hline 8 & 7.95 & 1.25 & 177 & 1.28 & 8.34 \\
\hline 9 & 7.9 & 1.25 & 179 & 1.25 & 8.37 \\
\hline 10 & 7.92 & 1.22 & 182 & 1.07 & 7.32 \\
\hline 11 & 7.91 & $1 . \overline{19}$ & 185 & $\overline{1.1}$ & 9.28 \\
\hline 12 & 7.92 & 1.2 & 186 & 1.02 & 6.73 \\
\hline 13 & 7.91 & 1.23 & 182 & 0.88 & 6.29 \\
\hline 14 & 7.95 & 1.22 & 186 & 0.87 & 5.8 \\
\hline 15 & 7.91 & 1.19 & 186 & 0.83 & 5.49 \\
\hline 16 & 7.95 & 1.19 & 189 & 0.84 & 6.83 \\
\hline 17 & 7.9 & 1.18 & 193 & 0.8 & 4.85 \\
\hline 18 & 7.92 & 1.17 & 190 & 0.78 & 5.69 \\
\hline 3PV & 7.84 & 1.17 & 208 & $<0.2$ & 0.95 \\
\hline 4PV & 7.71 & 1.09 & 217 & $<0.2$ & 0.55 \\
\hline 5PV & 7.71 & 1.13 & 214 & $<0.2$ & 0.79 \\
\hline MW1 water & 7.53 & 1.08 & 229 & $<0.2$ & 0.12 \\
\hline MW1-Post & i & 7 & & $<0.2$ & 0.4 \\
\hline MW6 water/sand & 7.76 & 1.55 & -96 & & \\
\hline MW1 Sample & 7.82 & 1.13 & 214 & $<0.2$ & \\
\hline
\end{tabular}




\begin{tabular}{|c|c|c|c|c|c|}
\hline Sample & $\mathrm{pH}$ & EC & Eh & $\mathrm{NH}_{4}{ }^{+1}$ & $\mathrm{NO}_{3}{ }^{-1}$ \\
\hline & su & $\mathrm{mS} / \mathrm{cm}$ & $\mathrm{mv}$ & $\mathrm{ppm}$ & $\mathrm{ppm}$ \\
\hline $1 \mathrm{~A}$ & 7.96 & 1.28 & 199 & 4.98 & 17.5 \\
\hline 1B & 7.97 & 1.25 & 172 & 4.66 & 14.3 \\
\hline 10 & 7.97 & 1.25 & 177 & 4.63 & 12.9 \\
\hline $1 D$ & 7.95 & 1.24 & 180 & 4.69 & 11.7 \\
\hline $1 E$ & 7.97 & 1.26 & 183 & 4.52 & 11.3 \\
\hline IF & 7.97 & 1.24 & 182 & 4.62 & 10.4 \\
\hline $1 G$ & 7.94 & 1.25 & 177 & 4.65 & 10.4 \\
\hline $1 \mathrm{H}$ & 7.93 & 1.22 & 180 & 4.55 & 9.48 \\
\hline 11 & 7.93 & 1.33 & 181 & 4.12 & 9.19 \\
\hline $2-1$ & 7.95 & 1.25 & 181 & 4.42 & 9.83 \\
\hline 2 & 7.95 & 1.27 & 180 & 4.57 & 8.42 \\
\hline 3 & 7.92 & 1.3 & 185 & 4.26 & 8.76 \\
\hline 4 & 7.91 & 1.23 & 183 & 4.48 & 7.48 \\
\hline 5 & 7.84 & 1.2 & 182 & 4.31 & 9.16 \\
\hline 6 & 7.86 & 1.19 & 182 & 4.31 & 7.02 \\
\hline 7 & 7.85 & 1.2 & 177 & 4.27 & 8.42 \\
\hline 8 & 7.86 & 1.19 & 178 & 4.14 & 10.3 \\
\hline 9 & 7.83 & 1.19 & 181 & 4.14 & 8.92 \\
\hline 10 & 7.85 & 1.19 & 182 & 4.06 & 7.9 \\
\hline 11 & 7.84 & 1.17 & 180 & 3.96 & 9.41 \\
\hline 12 & 7.85 & 1.17 & 179 & 3.92 & 7.89 \\
\hline 13 & 7.81 & 1.17 & 180 & 3.9 & 6.29 \\
\hline 14 & 7.85 & 1.17 & 186 & 3.73 & 5.96 \\
\hline 15 & 7.85 & 1.17 & 186 & 3.69 & 5.86 \\
\hline 16 & 7.85 & 1.16 & 186 & 3.57 & 5.44 \\
\hline 17 & 7.88 & 1.15 & 185 & 3.41 & 5.15 \\
\hline 18 & 7.86 & 1.16 & 182 & 3.36 & 5.53 \\
\hline 3PV & 7.7 & 1.11 & 206 & 1.09 & 2.24 \\
\hline 4PV & 7.77 & 1.12 & 215 & 0.27 & 0.69 \\
\hline $5 \mathrm{PV}$ & 7.76 & 1.13 & 213 & $<0.2$ & 1.1 \\
\hline MW1-initial & 7.57 & 0.99 & 198 & $<0.2$ & 0.23 \\
\hline MW6-initial & 7.55 & 1.39 & 142 & 40.3 & $<0.1$ \\
\hline MW1-Post & 7.91 & 1.13 & 210 & $<0.2$ & 0.78 \\
\hline Post-Water Below & 7.63 & 1.26 & 184 & 7.44 & 1.65 \\
\hline
\end{tabular}




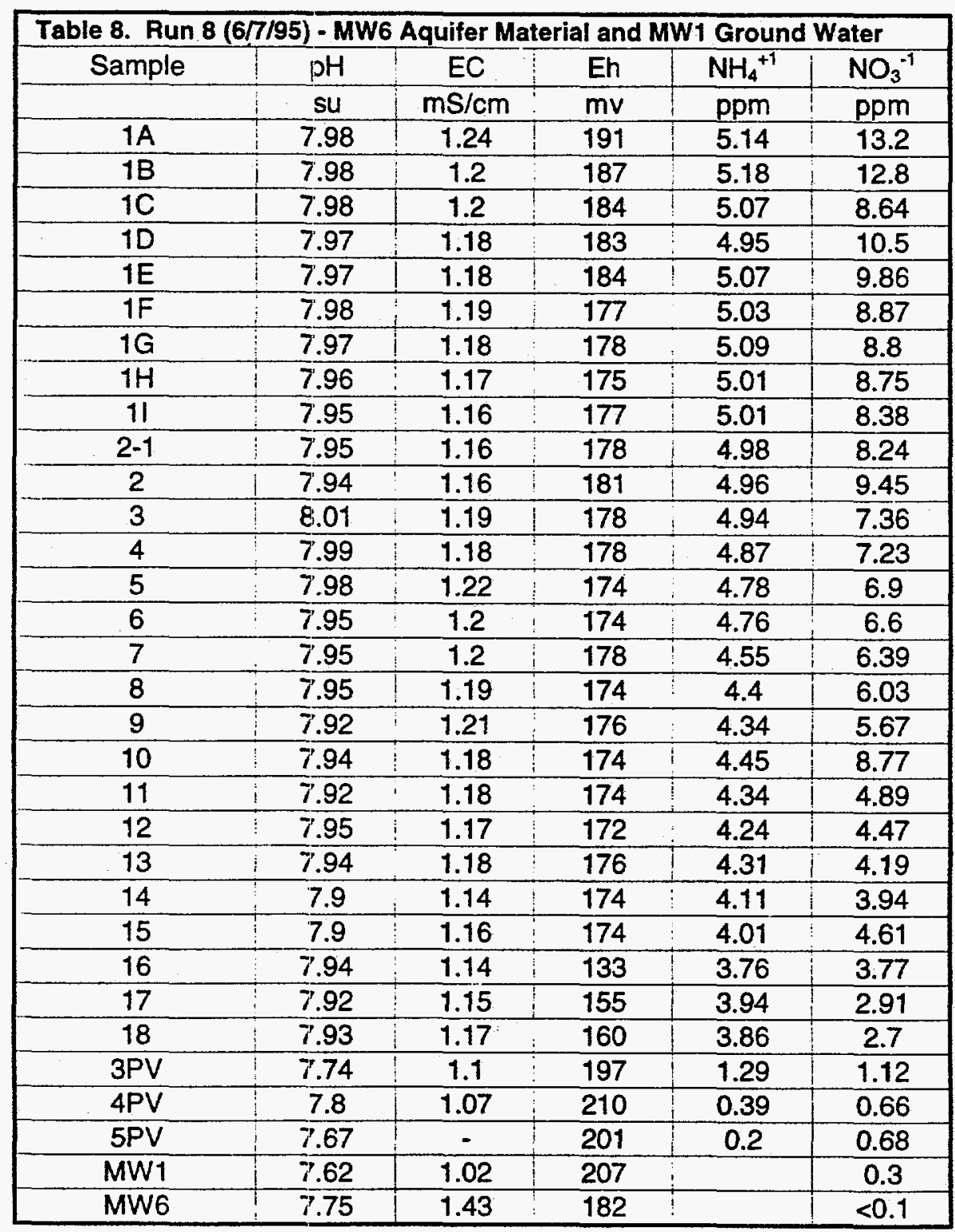

